\title{
Dona Heloisa e a pesquisa de campo
}

\author{
Mariza Corrêa \\ Unicamp
}

\begin{abstract}
RESUMO: Heloisa Alberto Torres (1895-1977) é uma personagem extensamente citada nas conversas de corredor das instituições nas quais a antropologia vem construindo a sua história e quase nunca citada em notas de pé de página. Qual foi, afinal, a contribuição desta personagem para a nossa história? Tento aqui começar a responder a esta pergunta, num ensaio que pretende ser também um estímulo aos jovens pesquisadores para visitarem nossos arquivos e ampliarem alguns dos indícios de que esta é uma história com um número muito maior de personagens do que estamos acostumados a considerar.
\end{abstract}

PALAVRAS-CHAVE: Antropologia brasileira, história da antropologia, gênero, Museu Nacional.

Itaboraí, a cerca de quarenta quilômetros de Niterói, terra natal do teatrólogo João Caetano e do romancista Joaquim Manuel de Macedo - mas não do político e intelectual Alberto Torres, que nasceu em seus arredores - foi o lugar escolhido por Heloisa e Maria (Marieta) Alberto Torres para viverem seus últimos anos de vida ${ }^{1}$. A casa que ambas 
compraram, e doaram ao Serviço do Patrimônio Histórico, é descrita nos guias locais como um "típico sobrado do século XVIII" e, depois de ter ficado anos fechada, foi reaberta em 1995 como Casa de Cultura Heloisa Alberto Torres, quase vinte anos depois de sua morte, em 1977 e, apropriadamente, no centenário de seu nascimento.

Heloisa Alberto Torres publicou muito pouco sobre as experiências de sua tão longa vida. Ingressou no Museu Nacional como auxiliar de Roquette-Pinto aos 23 anos, logo após a morte do pai, e tornou-se efetiva através de concurso prestado em $1925^{2}$. Logo no ano seguinte foi eleita chefe interina da Seção de Antropologia e Etnografia e chefe efetiva desde 1931; foi vice-diretora do Museu de 1935 a 1937 e diretora de 1938 a 1955: não foram apenas "dezessete anos de vida consumidos pela administração", como diz Castro Faria (1978), mas quase trinta só no Museu Nacional ${ }^{3}$.

Sua presença no cenário antropológico brasileiro foi marcante não apenas pelos atos administrativos que realizou, ou pelos trabalhos acadêmicos que deixou de realizar, mas pelo seu empenho na formação de jovens pesquisadores através da experiência da pesquisa de campo e no desenvolvimento da etnologia. Heloisa nunca sistematizou esta atuação, ou refletiu sobre ela em trabalhos publicados: mas ela aparece com clareza no que talvez seja o melhor de sua produção - sua correspondência com colegas e com jovens etnólogos cujas carreiras ajudou a animar. Era como se, para ela, o trabalho de campo se esgotasse em si mesmo - nunca chegou a publicar um relato de sua viagem à Ilha de Marajó, primeira pesquisa de campo que fez e, apesar de seu entusiasmo sobre a última, no Arraial do Cabo, também dela não deixou qualquer trabalho publicado ${ }^{4}$. Sua extensíssima produção não publicada revela, no entanto, um investimento enorme de energia nos bastidores da pesquisa de campo - fosse através da correspondência que mantinha com colegas ou agências de financiamento de pes- 
quisa, fosse através de projetos e relatórios de pesquisa ou da orientação que dava aos jovens pesquisadores.

Mais ou menos na mesma época em que, em São Paulo, a influência norte-americana parecia estar se consolidando nas ciências sociais através dos estudos sócio-antropológicos de comunidade, feitos principalmente por pesquisadores da Escola Livre de Sociologia e Política, no Rio, tal influência chegou através de gestões de dona Heloisa. Castro Faria menciona sua "intensa correspondência" com Franz Boas, Ralph Linton, Paul Rivet, Alfred Métraux e Charles Wagley recorda que "usando seu prestígio e ampla rede de amizades", dona Heloisa guiava os pesquisadores visitantes "através da intrincada burocracia, que exigia o registro de estrangeiros e uma permissão especial para realizar expedições científicas no país, além de vários outros documentos oficiais." (Wagley,1988). Wagley diz também que "A Universidade de Columbia mantinha um acordo informal com o Museu Nacional do Rio de Janeiro para co-patrocinar estudos etnológicos no Brasil." No âmbito deste acordo vieram para cá o próprio Wagley, William Lipkind, Buell Quain e Ruth Landes, primeiro, e depois James e Virginia Watson, Yolanda e Robert Murphy, entre outros. Nenhum deles ficou muito tempo no Museu, mas Heloisa tentava aproveitarse de sua estadia para treinar pesquisadores jovens. Numa carta de 1938, ela explica o seu plano a Buell Quain:

"Fiz algumas modificações no meu plano de curso do Museu. Pensei em transferir para um pouco mais tarde o curso de lingüística e adotar imediatamente um programa mais prático e que, segundo me parece, corresponde melhor às necessidades mais prementes do meu país. Para isso desejaria poder contar com o senhor e o Wagley. Durante o período de permanência no Museu, cada um se ocuparia uma hora por dia de um grupo de cinco pessoas para instrução etnológica de caráter essencialmente prático e faria os seus estudos pessoais e 
redação de pesquisas, durante o resto do tempo. Organizaríamos um plano de pesquisa sistemática de campo; cada qual, ao sair, levaria consigo um aluno. Espero que, com três anos de trabalho, nós teríamos talvez formado pelo menos uns três trabalhadores bons. O Sr. vai ficar surpreendido com a facilidade que o brasileiro tem para aprender. (...)

Não pretendo implantar (está reconhecendo?) ninguém no meu país; desejo apenas que meus amigos me ajudem no desenvolvimento de estudos etnológicos."

As inúmeras fotos da época, em que dona Heloisa aparece com pesquisadores norte-americanos que passavam pelo Museu, ilustram sua centralidade, que derivava tanto de sua posição institucional quanto de seu poder de acionar aquela ampla rede social referida por Wagley. Ilustram também a "troca de guarda" nas influências sofridas pelo país durante e logo após a Segunda Guerra, influências que igualmente se expressariam na antropologia como uma disciplina que começava a se constituir. A primeira influência é registrada pela linguagem: tanto Wagley como dona Heloisa falam, no início dos anos 40, em antropologistas (anthropologists) como os praticantes desta disciplina, sinalizando a influência do inglês e da relação com os norte-americanos, que passavam a ser mais presentes do que os franceses na vida intelectual do país. Numa entrevista com o presidente Vargas, a recémeleita diretora do Museu menciona o alto número de antropólogos empregados pelo governo norte-americano, mobilizados pelo esforço de guerra, e acrescenta: "uma vez terminado esse conflito todos os antropologistas ansiosos voltarão seus olhos para o Brasil, único ponto da terra cuja população primitiva, ou grande parte, ainda estará intacta em seus costumes e estado de cultura, tornando-se assim um valioso e inigualável campo de estudos e pesquisas." E sugeriu que fosse criada a carreira de antropologista e antropologista-auxiliar, sendo autorizada pelo presidente a elaborar um anteprojeto sobre o assunto ${ }^{7}$. Alguns antropólogos certamente voltaram os olhos para o Brasil, en- 
tre eles Charles Wagley que registra um dos primeiros encontros, no campo, de um antropólogo treinado com os jovens que Heloisa enviava para aprenderem com ele.

"Então, uma manhã, ouvimos um tiro de pistola. Um pouco mais tarde apareceram três brasileiros estranhos. Eram apenas três jovens - Eduardo Galvão, Rubens Meanda e Nelson Teixeira. Vinham do Museu Nacional, enviados por Heloisa Alberto Torres. Traziam cartas, revistas, notícias da guerra na Europa e uma garrafa de uísque. Suspeitei primeiro que fossem espiões, enviados para me fiscalizar e ao meu trabalho. Depois percebi que eram estudantes principiantes de antropologia. Eles traziam pouca coisa para trocar, mas sua presença nos trouxe a todos de novo à vida."8 (Wagley, 1988). Juventude e animação transpareciam também nas cartas trocadas pelos três aspirantes a antropólogos entre si, na época, em algumas fotos de campo ou em recortes de jornais, mostrando que todos defendiam com ardor a causa indígena na volta de suas expedições a lugares longínquos para onde dona Heloisa os mandava, acompanhando-os de longe com um misto de autoridade e afeto. Ambos estão bem expressos num telegrama seu aos pesquisadores, em 1942: "Reitero ordem máximo cuidado medicação preventiva malária ponto abraços afetuosos ponto Heloisa." Que as relações com a diretora do Museu eram afetuosas/ autoritárias são testemunhas também a suspeita inicial de Wagley à chegada dos jovens ao campo, as cartas afetuosas dela aos três (telefonando para a mãe de Galvão antes de escrever, ou passando um "pito" em Nelson Teixeira, por não se comunicar com a família), ou respeitosas de James Watson, um comentário de Wagley e uma curiosa alteração na dedicatória de seu livro com Galvão.

O comentário de Wagley é brincalhão mas revelador. Numa carta a Galvão, depois de dizer que antecipava a chegada dele aos Estados Unidos com "uma certa satisfação sádica" pelas dificuldades que ele teria com o idioma, o que seria a sua "vingança", acrescentava: "Em 
seguida quero ver Heloisa servida de uma dose da gíria estudantil e nova-iorquina - então meus longos anos de frustração serão aliviados"'. As cartas de Eduardo Galvão na época mostram tanto a evolução de suas relações com dona Heloisa quanto a de seu aprendiza$\mathrm{do}^{10}$. Primeiro com Wagley: "Wagley vae trabalhando ao mesmo tempo que nos orienta, de vez em quando passa uma revista nos cadernos e distribue alguns pitos. Iniciou agora uma série de leading questions que organiza e distribui por nós de modo a completarmos o material que vamos conseguindo." Depois com Watson: "O sistema de trabalho de Watson é bastante diferente daquele de Wagley, primeiro formulam-se os problemas para então investigá-los. Sem isso será quasi impossível (na opinião dele) fazer antropologia social, porquanto após o trabalho já não (há) mais possibilidade de resolver problemas, terse-á simplesmente um estudo extensivo e, não, intensivo como o Watson se propõe a fazer." Watson distinguia etnologia ("histórica") de antropologia social ("científica")."Chegamos à conclusão," diz Galvão com ironia, "que para tornar os inquéritos em antropologia social é suficiente antepor-lhes explicitamente os problemas requeridos." Galvão achava o método, que envolvia a formulação prévia de questionários exaustivos e justificativa das questões a estudar, "um tanto complicado e menos eficiente do que o de Wagley". Descrevendo Watson e sua esposa Virginia como muito formais e desconfiados, dizia dele: "Ele ainda não compreendeu a necessidade social do 'lero-lero'." E encerra: "Saudades dos futuros "antropólogos sociais""11.

Escrevendo de São Paulo, na véspera de partirem para uma "field trip" em Goiás, James Watson, que estava acompanhado de sua esposa Virginia, consulta dona Heloisa sobre como orientar os jovens pesquisadores:

“(..) a questão é a seguinte: a vontade da Senhora. Se quiser que eu faça sugestão ou empreste a mão de vez em quando para guiar ou Galvão ou Teixeira, ou melhor, só para indicar a variedade de pen- 
samento que existe e que eu conheço num assunto marcado, muito bem. (..) Eu acho que há bastante trabalho para todos nós, dentro do tempo indicado, concentrar completamente no assunto da economia. Isso não quer dizer que a gente vai negligenciando o resto, pois segundo o ponto de vista funcionalista, qualquer parte se liga com o resto da cultura, numa maneira ou outra. (..) O que eu quero aprender, então, é se a Senhora quer uma direção unificada, um 'emphasis' particular, um fim, que toca primeiramente os problemas da organização econômica, que foi meu plano original, mas com observações bastante amplas sobre outros aspectos da cultura, indicando porém que estes outros aspectos da cultura não foram o maior fim desta 'field trip'. Parece que há bastante precedência para este tipo de estudo, aliás, que isso talvez representa uma das maiores tendências da antropologia atual. Mas, enfim, estou de vontade fazer só o que a Senhora quiser neste respeito."12

O português arrevesado de Watson não esconde que ele tinha um projeto bem definido, mas que estava disposto a ajudar os jovens brasileiros em sua aprendizagem, como Heloisa queria. $\mathrm{O}$ que ela confirma em outra carta:

"Gostei de duas notícias: de que o Watson se presta com satisfação a ensinar e que a saúde é muito boa. Os outros pequenos detalhes são poeira de estrada; o importante é chegar ao fim."13

Alguns desses jovens foram até o fim; outros ficaram pelo caminho. Depois de alguns anos dessa aprendizagem, Eduardo Galvão estava pronto para obter seu doutorado em Columbia, onde foi o primeiro $\mathrm{PhD}$ formado sob a orientação de Charles Wagley e provavelmente o primeiro brasileiro a obter este título em antropologia ${ }^{14}$. Seus dois companheiros de pesquisa tomaram outros rumos, apesar de terem participado de pelo menos uma terceira experiência de campo, entre os Tenetehara. No prefácio à edição brasileira de seu livro sobre este grupo indígena, Wagley e Galvão os mencionam pela última vez: "Nelson Teixeira e Rubens Meanda não puderam participar da preparação 
dos dados de campo para publicação. Eles colocaram todas as notas à nossa disposição e leram longos trechos deste relato. Desejamos agradecer-lhes por sua íntima colaboração e dar-lhes o crédito devido por suas precisas observações de campo." 15

O antropólogo mais velho - Wagley tinha 32 anos e Galvão 24 na época dessa pesquisa - cumpria à risca o prometido à dona Heloisa, fazendo sugestões detalhadas ao jovem antes de Galvão retornar ao campo:

"Recém terminei de escrever o rascunho da primeira parte do ciclo de Vida, a partir do texto tentativo de Rubens e das notas de campo. Reorganizei inteiramente o material: ele ficou mais ou menos assim Casamento, Estabilidade do Casamento, Divórcio, Viúvas, Tabus pré e pós natal, Nascimento, Cuidados com o bebê, Infância, Puberdade. Acho que o trecho que Rubens entitulou Doenças-Morte (do qual você tem uma cópia) deveria ser inserido na parte sobre Religião.(...) Por favor, reescreva o trecho Doenças-Morte. Ele está vago e redundante, etc. Enfatize a economia, claro, e obtenha bom material. Deve ser o capítulo mais fraco. Leve junto alguns livros para inspirar-se sobre questões importantes - você pode até levar aquele grande clássico sobre a Guatemala. Estou datilografando o que escrevi e o mandarei a você no campo - dentro de um mês. Leia cuidadosamente e reescreva parágrafos - sugiro numerar os parágrafos (temporariamente) à la Nimuendaju para que não se perca a continuidade - reescreva acrescentando material novo. Deixe os mitos comigo - assim poderei trabalhar sobre eles." ${ }^{16}$ (Wagley e Galvão, 1961).

Além de mostrar a organização de uma monografia antropológica na época, as sugestões revelam também um pouco do clima de parceria que tinha se estabelecido entre eles. Ambos dedicaram a versão em inglês do livro, de 1949, à dona Heloisa mas, quando saiu em português, em 1961, com dois apêndices novos de Galvão, ele foi dedicado a Nelson Teixeira, já falecido. As dificuldades que Galvão enfrentou para obter licença do Museu Nacional para fazer o curso de 
doutorado em Columbia podem responder em parte ao porque desta alteração, mas seria preciso saber mais a respeito da nova relação entre dona Heloisa, então no Conselho Nacional de Proteção aos Índios, e Eduardo Galvão que, ao voltar dos Estados Unidos, fora trabalhar no Serviço de Proteção aos Índios com Darcy Ribeiro, para entender melhor suas posições em instituições que estavam estruturalmente em confronto ${ }^{17}$.

Confronto é uma palavra que poderia sintetizar boa parte da atuação de Heloisa no mundo intelectual de sua época: portadora de um nome importante neste mundo, ela ocupou inúmeras posições politicamente importantes, a maioria vinculada diretamente à disciplina à qual dedicou o melhor de seus esforços, outras apenas indiretamente: todas, no entanto a colocavam no centro do palco numa época em que poucas mulheres lá estavam. A fotografia dela como delegada do Brasil numa reunião da UNESCO, única mulher numa fieira de homens, é tanto emblemática de sua importância, como mostra que o cenário internacional não era muito diferente do nosso. Tais posições eram disputadas e, a julgar pelas que ocupou, Heloisa era uma hábil jogadora. Duas das disputas nas quais ela se envolveu merecem ser avaliadas aqui porque ilustram também disputas mais amplas no campo do saber: a disputa pela direção do Museu Nacional, que a envolveu num conflito público com alguns de seus naturalistas e a disputa pela cátedra de Arthur Ramos. Na primeira, dona Heloisa saiu vencedora; a segunda, ela perdeu.

Em 1939, visitando dona Heloisa e o Museu Nacional, Alfred Métraux registra em seu diário que o prédio "ménace ruine"; dois anos depois Heloisa obtém verba do governo federal para os consertos do edifício e parte dele fica fechado ao público. As obras interferem também no andamento do trabalho em alguns setores e serão o principal motivo de queixa de alguns naturalistas no momento em que a crise se torna pública com a questão da eleição no $\mathrm{Museu}^{18}$. Em seu depoi- 
mento no processo aberto pela reitoria da Universidade do Brasil, Heloisa vai dizer que a hostilidade anterior de alguns de seus colegas era "discreta e intermitente", nunca tendo impedido "manifestações de cortesia" e que "nunca o trabalho no Museu se ressentiu desse movimento". Mas o aviso do ministro da educação, "tornou naturalmente mais viva e apaixonada a aludida campanha cuja acrimônia pode ser verificada documentadamente pela entrevista concedida, na véspera da eleição, pelo naturalista Newton Dias dos Santos no vespertino Diário da Noite."19

O Museu Nacional esteve vinculado ao Ministério da Agricultura até 1930, quando passou ao Ministério da Educação e Saúde. Em 1937, com a criação da Universidade do Brasil, ficou ligado a ela, até 1941, quando voltou ao Ministério da Educação e Saúde até 1945, tendo, desde então, retornado ao âmbito da Universidade do Brasil, depois Federal do Rio de Janeiro. Em 1945, no contexto das eleições gerais no país, o ministro da educação enviou um aviso ao Museu para realizar eleições para a direção. Heloisa pediu um representante do ministério para conduzir o processo e, não tendo recebido resposta, decidiu não presidir a eleição, para mostrar sua isenção. Apesar disso, o processo eleitoral foi conturbado. Além da entrevista mencionada por ela, dada na véspera da eleição por um dos chefes de seção do Museu, no dia da eleição, a mesa que ela indicara para presidi-la foi contestada e, na confusão que se seguiu, foram feitas duas atas da eleição: uma com os incidentes do dia e outra apenas com os resultados que foram enviados ao ministério.

Na sua entrevista, Newton Dias dos Santos, chefe da Seção de Zoologia, acusava Heloisa de ter perdido peças do Megatherium, um antepassado da preguiça, que fora desmontado para mudar de sala; de descuido com os sarcófagos das múmias, que estariam danificados, e de vários outros descuidos com o material do Museu. A página de jornal com a entrevista foi afixada nas escadarias do Museu no dia da eleição. Neste dia, um dos indicados por Heloisa para compor a mesa eleitoral recusou-se a fazê-lo e dois de seus opositores tentaram impugnar 
a mesa, dizendo que ela não merecia a confiança da "assembléia soberana". Um dos integrantes da mesa, José Cândido de Carvalho, sentiuse "gravemente injuriado" por suas palavras e esbofeteou Newton Dias dos Santos. O fato foi registrado numa ata separada e, tendo prosseguido a eleição, o resultado foi o seguinte: Othon Leonardos, 21 votos, Heloisa Alberto Torres, 11, Antenor Leitão de Carvalho, 1, José de Araujo Lacerda Feio, 1, Newton Dias dos Santos, 1. Othon Leonardos chegou a ser nomeado por decreto presidencial, em fevereiro de 1946, mas, como a data era posterior ao decreto que reintegrava o Museu à Universidade, a nomeação ficou sem efeito ${ }^{20}$.

Os jornais continuaram, no entanto, a tratar do caso durante o resto do ano e a publicidade das acusações à diretora do Museu fez com que a Universidade abrisse um processo administrativo para esclarecê$\operatorname{las}^{21}$. As acusações feitas pelos naturalistas no processo são de várias ordens, desde a falta de armários para a guarda das coleções ("Não seria melhor comprar armários que cortinas e outros enfeites?"), passando pela cozinha, pequena para o almoço de todos ("Se houvesse boa vontade da diretora...") e pelo uso do livro-ponto, até o estado dos sarcófagos das múmias e o desmonte do Megatherium. Heloisa prepara um longo documento em que responde cuidadosamente a cada uma das questões, nos casos mais sérios, incluindo a avaliação de especialistas, de Alberto Childe, sobre os sarcófagos e de Llewelyn Ivor Price sobre o Megatério, em outros, com uma ponta de ironia. Sobre o livro-ponto, diz que era uma recomendação dos próprios funcionários: "Parecem ter mudado de opinião."22 Sua conclusão é ríspida: "Faltaram, em auxílio à obra empreendida pelo Diretor do Museu, por parte de alguns espírito de compreensão da fase inconfortável de trabalho que era inevitável atravessar e sobretudo faltaram-lhe chefes, que dirigissem cada um dos setores de atividades em que se dividia o Museu."

Heloisa certamente contrariou interesses individuais ao não autorizar o pedido de comissionamento de alguns dos naturalistas que a criticavam, pedido feito um pouco antes da crise; mas ela é também insti- 
tucional e aponta tanto para a redefinição do lugar dos museus no cenário educacional brasileiro quanto para a diferenciação da Antropologia em relação às suas vizinhas (Geologia, Botânica e Zoologia) no Museu Nacional. Uma das críticas feitas à diretora era que ela não reunia a Congregação. Heloisa responde dizendo que a estruturação da carreira de naturalista, por lei de 1936, extinguira a carreira de professor no Museu e que, segundo o ministério, só professores podiam ter assento na Congregação. Quando assumiu a direção do Museu, apenas dois naturalistas, além dela mesma, eram professores concursados, Roquette Pinto e Jorge Padberg Drankpol, e ambos estavam afastados. A centralização do sistema educacional, iniciada pela reforma Francisco Campos em 1931; a extinção da carreira de professor nos museus; a desacumulação de cargos, tornada obrigatória na Constituição de 1937, e o papel central atribuído às Faculdades de Filosofia como núcleos de irradiação do saber, desde 1934 em São Paulo e de 1939 no Rio de Janeiro, começavam a deslocar os museus de ciências naturais da posição central que eles até então ocupavam ${ }^{23}$.

Outras críticas feitas a Heloisa sugerem que suas iniciativas de explicitar a separação que começava a se dar entre a antropologia e suas vizinhas no Museu não foram bem recebidas. Uma delas dizia respeito à criação de séries separadas de publicações para a Antropologia, a Botânica, a Geologia e a Zoologia - ao que ela responde com as exigências de especialização, já que as instituições com as quais o Museu intercambiava publicações nem sempre se interessavam pelo conjunto destas áreas. Pascoal Leme, o encarregado de editar essas novas publicações foi também atacado pelos opositores de Heloisa, que o acusavam de exercer censura sobre os manuscritos e de "comunista" ${ }^{24}$. Mas outra era mais específica e expressava um desacordo sobre o que seria legítimo expor na vitrine da ciência do país que era o Museu. A certa altura do rol de acusações que fazia à diretora, Othon Leonardos, falando da Exposição dos Centenários, em Portugal, em 
1940, diz que "os mostruários enviados por Dona Heloisa a Lisboa, chegaram a ser arrumados no pavilhão brasileiro mas não foram exibidos ao público porque a Comissão julgou deprimente apresentar o Brasil como um país de negros e macumbas", citando os membros da comissão organizadora nominalmente (Augusto de Lima Junior, Gustavo Barrozo, Guy de Hollanda e Ernesto Street) como fontes de confirmação. A resposta de Heloisa foi incisiva:

"Há um ponto que merece réplica, acima de todos: O Museu Nacional, solicitado a apresentar aspectos etnográficos da população brasileira, não poderia, a bem da verdade científica, esconder o elemento negro da nossa população, elemento a que tanto deve o país. O conceito de superioridade de raça - que tal omissão denunciaria - é anticientífico e... para os grandes apregoadores de doutrinas liberais (o que o senhor Othon Leonardos afeta de ser) é antidemocrático. O negro existe, tem sido explorado, trabalha, contribuindo de modo decisivo para o progresso do país e tem que aparecer em qualquer certame que envolva aspecto científico antropológico onde quer que o Brasil se faça representar." 25

Esgotadas as críticas à administração de Heloisa, seus opositores começam a expor seus preconceitos de raça e de gênero. $\mathrm{O}$ documento produzido para a reunião do Conselho Universitário na qual a questão seria decidida é onde finalmente o conflito entre diretor e diretora se manifesta ${ }^{26}$. Pedindo ao Conselho "a graça" de um interventor no Museu, os signatários acusam Heloisa de "asfixiar a ciência", "manejar como fantoches os cientistas" e abrir caminho "para a peor e mais intolerável das prepotências: a prepotência feminina, instaurando um regimem de matriarcado e perseguição aos que lhe caem no desagrado. ${ }^{27} \mathrm{E}$, mais adiante, apelam para a hombridade do Conselho: "A situação não é mais para contemporizações ou afetividades. É muito tarde para assim pensar. O caso atual do Museu está acima das amizades e dos pontos de vista pessoais. O Egrégio Conselho Universi- 
tário é composto de homens livres, diretores, pensadores, cientistas, educadores, juristas, etc." Ironicamente, depois de terem atribuído os elementos de afetividade ao universo semântico feminino, por oposição ao masculino, livre dessas injunções, os signatários do documento fazem o que em sua lógica seria um elogio à Heloisa: "Todavia, não faltou quem tivesse a coragem de lhe advertir sobre o futuro, mas sempre declarou que não se interessava por rumores." 28 Talvez por isso a carta anteriormente citada, escrita para a comissão, não tenha sido afinal enviada, já que nela os partidários de Heloisa utilizavam argumentos do mesmo tipo dos usados aqui, isto é, que denunciavam o seu opositor, colocando-o numa posição simétrica e inversa, por ser pouco masculino - assim como Heloisa era, aparentemente, muito feminina para ocupar a posição que ocupava ${ }^{29}$. Isto é, ambos os grupos em conflito parecem concordar em que o perigo estava na poluição das fronteiras entre o masculino e o feminino, pela ocupação de lugares socialmente, explícita ou implicitamente, destinados a uma destas categorias, mas não à outra ${ }^{30}$. Que a disputa era reconhecida na época pelos personagens do campo intelectual, fica claro também na apreciação de dois de seus contemporâneos ilustres que, um, tentou apropriála para a categoria masculino; o outro, ironizou a categoria feminina. Afrânio Peixoto, num cartão de agradecimento, com timbre da Academia Brasileira de Letras, ilustra a tentativa de apropriação: "Não me enganou o instinto, quando pensei que o Museu devia estar entregue a homem - mais que homem é uma mulher e senhora-sábio, pois que V.Excia. não é outra coisa." Herbert Baldus, agradecendo a boa acolhida que teve no Rio, é mais irônico e parece aludir à situação do Museu no ano em que lá esteve: "Fiquei encantado com a doce ginecocracia (cf. esse termo no Dicionário de Etnologia e Sociologia de Baldus e Willems), e quase me veiu a vontade de tornar-me um de seus súditos. Acho, porém, mais conveniente, ficar aqui na qualidade de seu representante diplomático e esperar a sua visita em abril.."31 
Na segunda disputa importante em que se envolveu, Heloisa enfrentaria o outro antropólogo que tinha o mesmo estatuto que ela no cenário carioca: Arthur Ramos. No primeiro caso, Heloisa mostrou que, apesar de mulher, era a mais forte nas circunstâncias; as circunstâncias serão diferentes no segundo caso, no qual outra mulher parecia ser a sua opositora.

Segundo Castro Faria, Heloisa foi indicada por Gilberto Freyre para substituí-lo na cátedra de antropologia da Universidade do Distrito Federal, criada em 1935 e que teve vida curta, encerrando suas atividades três anos depois. No mesmo departamento, Arthur Ramos ocupava a cátedra de psicologia. No âmbito da disputa política pelo controle da educação superior no país, foi criada a Faculdade Nacional de Filosofia da Universidade do Brasil e, em novembro de 1939, Ramos foi indicado para ocupar a cátedra de Antropologia e Etnografia $^{32}$. Uma oposição análoga a que os contemporâneos liam em São Paulo nas relações entre a Escola de Sociologia e Política e a Faculdade de Filosofia pode, a partir daí, ser lida nas relações entre o Museu e a nova faculdade ${ }^{33}$.

A Faculdade passou a ser o centro de atuação de Arthur Ramos, provavelmente o antropólogo mais importante na cena nacional naquele momento e que fundou, junto à cadeira que regia, a Sociedade Brasileira de Antropologia e Etnologia (1941-1949) por onde circularam quase todos os antropólogos que visitaram o país e muitos pesquisadores nacionais ${ }^{34}$.

Sua viagem aos Estados Unidos, as relações acadêmicas que lá estabeleceu, em 1941, e as posições públicas que assumiu durante o Estado Novo, fosse na defesa da luta dos negros pela cidadania, fosse contra o nazifascismo que tomava conta de parte da Europa, lhe deram a partir daí uma posição tão central na política da disciplina quanto a ocupada por Heloisa até então.

A convivência de ambos parecia no entanto pacífica, a julgar por dois exemplos, citados por Azeredo: uma carta de Heloisa a Arthur Ramos, 
em 1941, oferecendo-lhe uma oportunidade de cooperação entre as duas instituições e outra, do mesmo ano, propondo a realização do Primeiro Congresso Brasileiro de Antropologia.

Na primeira carta, Heloisa reafirma sua ênfase no trabalho de campo como treinamento necessário do antropólogo:

"Apresenta-se agora uma oportunidade feliz de reiterar-lhe o oferecimento - feito no dia da instalação dos cursos da Universidade do Brasil - de cooperação entre o Museu Nacional e a sua cadeira de Antropologia. Está trabalhando conosco o Dr. Charles Wagley, da Universidade de Columbia, que deu início à instrução de alguns rapazes, em etnologia. Afim de que esses trabalhos tenham maior repercussão, pareceu-nos conveniente, ao Dr. Wagley e a mim consultá-lo sobre o interesse que teriam alunos da Universidade em frequientar essas aulas. Devido a certas condições de instalação de trabalho e ao método de ensino adotado, sou forçada a limitar o número de alunos a serem admitidos no curso. Sua duração será de cerca de três meses, findos os quais alguns rapazes deverão seguir para o campo com o Dr. Wagley."

Tal cooperação, segundo o pesquisador que analisou a documentação, parece não ter se concretizado. No fim do mesmo ano, Heloisa escreve a segunda carta:

"O projeto de promover o Primeiro Congresso Brasileiro de Antropologia para comemorar a reabertura do Museu Nacional (meados de 1943) foi recebido pelo Governo com a máxima simpatia. Eu não tinha querido dar nenhum passo nesse sentido antes de conhecer o pensamento das autoridades. Agora recebi ordem para organizar com urgência o plano; afim de obter seu concurso nesse trabalho, venho convidá-lo para um pequeno jantar a ter lugar depois de amanhã, 12 de novembro, às 20 horas no restaurante Santos Dumont."

Não sabemos se o jantar se realizou mas este empreendimento, iniciado por Heloisa, levaria mais de dez anos para se concretizar: so- 
mente em 1948 o Ministro da Educação e Saúde, Clemente Mariani, designou, através de portaria, uma comissão para organizar o Primeiro Congresso Brasileiro de Antropologia. Ignorando possíveis tensões locais, eram designados para compor a comissão Alvaro Fróes da Fonseca, Edgar Roquette-Pinto, Arthur Ramos e Heloisa Alberto Torres. A comissão se reuniu em fevereiro de 1948 - sem a presença de Heloisa e de Ramos, ambos representados por Castro Faria que já tinha feito um documento sugerindo à diretora do Museu os parâmetros da reunião ${ }^{35}$. Ela foi, afinal, realizada no Museu Nacional, em 1953, sob a presidência de Herbert Baldus e ali nasceu a idéia da criação da ABA, Associação Brasileira de Antropologia, concretizada dois anos depois na Bahia.

As relações entre ambos se tornaram mais tensas no início de 1946, quando Arthur Ramos defendeu sua tese de livre docência, "A organização dual entre os índios brasileiros", para ocupar formalmente a cátedra que regia. Dona Heloisa fazia parte da banca, da qual participaram também Faria Góis e Fróes da Fonseca e, segundo Costa Pinto:

"O Ramos jamais perdoou Heloisa (...) o fato dela haver feito ironia com um erro de tradução do Ramos, que confundiu log race com dog race, e disse que isso era um esporte favorito dos índios, quando na verdade o índio só conheceu cachorro muito depois, trazido pelos europeus. A corrida era arrastando um toro de madeira (log), e há enorme diferença entre toro e totó." 36

Quarenta anos depois Castro Faria ainda recordava a anedota, uma das mais recorrentes da história da antropologia dessa época, em seu depoimento na UnB. No contexto das disputas de então, o depoimento de Castro Faria pode ser lido também como a defesa de um grupo e de seus objetivos, o do Museu, contra outro, o da Faculdade, seja na desqualificação do conhecimento etnológico de Arthur Ramos, que ele definia como produtor de um conhecimento, literalmente, "de cátedra" sobre o negro brasileiro, seja na crítica à sua orientação teórica. 
Referindo-se à Introdução à antropologia brasileira de Ramos, Castro Faria afirma: "Esse compêndio tornou-se o veículo, por excelência, do culturalismo da antropologia norte-americana". E, discutindo o programa da cadeira da Faculdade, publicado por ocasião do edital de concurso para substituir Arthur Ramos, admite a troca da palavra etnografia, oficial, por etnologia, como ocorrera no edital, mas adverte: "Chamar de 'antropologia cultural', cujos novos métodos o professor dizia seguir, isso seria impossível." A conclusão é clara: "Tal quadro mostra que, na realidade, o ensino de Antropologia nas Faculdades de Filosofia não oferecia condições para a formação de antropólogos." ${ }^{37}$

O conflito expresso por aquela anedota vai assim muito além de um mero "facciosismo" entre duas instituições - uma de ensino, outra de pesquisa - e mostra que as relações tensas entre a diretora do Museu e o catedrático da Faculdade de Filosofia definiam também os termos de uma disputa interna ao campo da disciplina: seu objeto, seu método de pesquisa e sua "identidade social", isto é, o sítio institucional da nova disciplina ${ }^{38}$.

Em 1949, quando Arthur Ramos aceitou o convite para dirigir o Departamento de Ciências Sociais da UNESCO, as relações entre eles atingiram um ponto crítico, ao tornar-se pública a disputa pela interinidade da cátedra - entre Heloisa e a assistente de Ramos, Marina Vasconcelos ${ }^{39}$.

Heloisa escreveu a Arthur Ramos, avisando-o de sua intenção de candidatar-se para substituí-lo em sua ausência: "Não quis, portanto, em face dos compromissos provavelmente assumidos por V.S. colocálo em atitude negativa à minha aspiração, posição essa que poderia resultar em constrangimento para V.S. dada a cordialidade de relações que, desde 1930, sempre existiram entre nós. É com prazer que as relembro, reavivadas que foram por ocasião de seu concurso em que tive a honra de figurar como examinadora e ainda recentemente quando juntos planejamos o futuro Congresso Brasileiro de Antropologia." 
Em sua resposta, Arthur Ramos foi extremamente direto: não haveria vacância da cátedra, e sim um simples afastamento; sua assistente nada pleiteara e sua indicação fora feita pelo catedrático. "E mesmo que a minha ausência temporária possa ser interpretada como vacância, há normas éticas, sempre respeitadas por aqueles que se dedicam à vida universitária, para o acesso aquelas posições que os conduzirão aos postos do professorado. O contrário disso seria a subversão completa dessas normas e um desestímulo à carreira de professor." Lembrando que Marina era sua assistente há nove anos e que seus planos no exterior, apoiados pelo Ministro da Educação, o reitor da Universidade e o diretor da Faculdade, dependiam de uma continuidade do programa por ele iniciado, Arthur Ramos conclui afirmando que Heloisa "não é membro do corpo docente da Universidade, não sendo livre-docente." "V.S. é diretor técnico-administrativo de um Museu, que requer de sua capacidade as suas melhores energias, o seu maior devotamento e até, por lei, o seu tempo integral." Ao tentar desqualificar sua pretensão de assumir uma cadeira como docente, além de reforçar a distinção entre a Faculdade e o Museu, Arthur Ramos parecia também ver em Heloisa uma representante do que considerava a velha antropologia, ou "ciência de museu". ${ }^{40}$

Arthur Ramos morreu em Paris - como seu mestre Nina Rodrigues, tornando mais lúgubre essa disputa prévia de sua cátedra - sem saber o desfecho da história ${ }^{41}$ que o preocupou até o final da vida, como mostra Azeredo e, embora sua assistente tenha, afinal, se tornado sua substituta como ele queria, os interesses que Heloisa representava foram, a longo prazo, vitoriosos no campo da antropologia: a pesquisa de campo é o modo de acesso privilegiado à profissão, a etnologia teve um papel muito mais central do que a "etnografia do negro" na constituição da disciplina em moldes contemporâneos e, ao contrário de Arthur Ramos, Heloisa teve êxito na formação profissional de pelo menos um dos vários jovens que estimulou a seguir a carreira de antropólogo. 
Enquanto a questão não se decidia, Heloisa parece ter hesitado sobre o trabalho a apresentar para o concurso à cátedra de Ramos: entre seus papéis no Museu Nacional há parte de um trabalho datilografado, já com página de rosto, onde se lê: "Tese apresentada para concurso à cátedra de antropologia e etnografia da Faculdade Nacional de Filosofia, Rio de Janeiro, 1950".

O trabalho tem por título Observações antropométricas e é uma retomada dos dados de uma pesquisa feita em 1922, no contexto de uma pesquisa mais ampla de Roquette-Pinto sobre a população brasileira. Das 700 fichas antropométricas dessa pesquisa, Heloisa se propunha a analisar 184, todas de mulheres entre 19 e 24 anos, "domésticas, empregadas de escritórios, de lojas, oficinas ou fábricas do Rio de Janeiro" "2. Na introdução, Heloisa mostra um interesse que infelizmente não desenvolveu em nenhum trabalho, mas que aparece em quase todos os seus textos. Diz ela: "O número de observações pode parecer pequeno; mas quando se atenta para a escassez de informações existentes sobre antropometria de mulheres no Brasil, ele avulta e assume proporções que o torna merecedor de maior interesse. A pobreza de conhecimento sobre o assunto reveste de maior relevo a documentação em causa." ${ }^{33}$ Queixando-se da "tarefa árdua" que foi entrevistar aquelas moças, já que elas "furtavam-se a observações sob alegações de uma série intérmina de preconceitos, ora de origem supersticiosa, ora de pretensa ordem moral", Heloisa tentava, quase trinta anos depois da realização da pesquisa, recuperar os objetivos da proposta de Roquette-Pinto: "verificar o grau de expressão de cada traço racial em uma população heterogênea racialmente falando". Apesar de toda uma discussão metodológica sobre a qualidade dos dados, das fichas e gráficos que acompanham o texto, ele foi deixado inacabado, talvez porque, ao contrário de Roquette-Pinto, Heloisa não tenha mais conseguido encontrar uma "lógica racial" nesses dados. Como ela diz, à certa altura, "a média da idade púbere pouco difere 
no grupo negróide e caucasóide". Já havia uma incompatibilidade entre a ciência aprendida por ela na juventude e os novos ares da antropologia - como ela mesma dissera ao defender sua escolha do que apresentar na exposição em Lisboa. A sua definição do grupo com o qual trabalhara já é inteiramente distinta das definições de RoquettePinto: ela define as moças entrevistadas como "um grupo homogêneo pela sua autonomia financeira." 44

Talvez por isso Heloisa tenha se decidido a elaborar outra tese para o concurso, esta acabada, impressa de acordo com o regulamento e também trazendo na capa a inscrição: Tese apresentada ao concurso para provimento da cadeira de Antropologia e Etnografia da Faculdade Nacional de Filosofia da Universidade do Brasil, Rio de Janeiro, 1950. Intitulada Alguns aspectos da indumentária da crioula baiana, sua apresentação é mais incisiva, já nas primeiras palavras da introdução:

"O presente trabalho abrange parte de um tema de pesquisa que, há alguns anos, prende nossa atenção. Numa sociedade como a nossa, formada por colonização, algumas dezenas de anos de independência política não chegaram a apagar a orientação econômico-social que proporcionou ao regime patriarcal sua mais ampla e pacífica expansão. Nesse regime, a mulher nasceu, cresceu e - com exclusão da professora - passou a vida limitada a um mundo tão alheio aos interesses da cultura, da inteligência e do espírito, como estranho ao campo da atividade social direta."

Depois de citar alguns "tipos culturais femininos", como a fazendeira, a comerciante, a rendeira, Heloisa diz que a crioula baiana "pela prática de várias e complexas atividades e pelo exercício de funções reconhecidas como masculinas pela sociedade, desenvolveu uma feição própria, original e definida."

A partir de suas entrevistas com 22 mulheres, entre 40 e 94 anos (cuja "solícita e leal atenção" ela elogia, o que parece opô-las às entrevistadas da outra pesquisa), Heloisa vai analisar os usos do pano da 
costa pelas baianas. Sua atenção, no entanto, se detém mais no detalhe técnico da tecelagem dos panos - cor, textura, tipo de tear ou de fio utilizado - ao fazer a análise; a apresentação do uso deles, no cotidiano, em festas ou cerimônias religiosas, fica por conta das belas fotografias anexadas ao trabalho ${ }^{45}$. É interessante que, embora hesitante sobre o trabalho a levar ao concurso, Heloisa tenha pensado em dois trabalhos que, pelo tema, estavam, ambos, na órbita do interesse de Arthur Ramos - o do estudo do negro brasileiro, e não em algum tópico em que pudesse utilizar os estudos etnológicos patrocinados ou estimulados pelo Museu. E que, nos dois casos, tenha pensado - no que seria a formulação contemporânea do problema - na relação entre raça e gênero.

Neste trabalho, de certo modo, Heloisa retomava um interesse de pesquisa que já aparecia em seu primeiro trabalho, sobre a cerâmica de Marajó, no qual dizia: "A técnica é educativa". Mas seu interesse pela parte técnica da cerâmica, também lá não a impediu de interessar-se pelas mulheres. As observações vêm bem ao final do trabalho:

"No curso de trabalhos da natureza dos que venho fazendo atravessam-se momentos de intensa emoção.

Sempre havia sido para mim motivo de orgulho considerar que, na região da América em que só mulheres são oleiras, tinha-se desenvolvido na cerâmica a arte mais rica, sóbria e vigorosa.

Objetavam-me alguns senhores - que, sim, seriam mulheres as oleiras mas que tratando-se de arte aplicada a fins religiosos, no momento da decoração certamente passaria a tarefa ao sacerdote. Certo. Nada a replicar.

O encontro em cronistas de descrição do fabrico da cerâmica e da sua ornamentação exclusivamente feita por mulheres no litoral sul do Brasil, veio despertar em mim novas esperanças de que a mulher, também em Marajó, tivesse sido a executora dos ornatos. Mas agora, em face de tudo o que acabamos de passar em revista, forçoso é reconhecer que a arte se desenvolveu nas mãos do homem a quem competem, em geral, os trabalhos de trançados. 
Se, na realidade, tal se deu, não se pode atribuir ao homem a responsabilidade completa da arte que criou; ele sofreu, por assim dizer, um certo constrangimento imposto pela matéria prima que concorreu para imprimir mais seguramente a sua expressão artística. Não foi completamente por culpa própria que atingiu a tamanho resultado.

Por sua vez a mulher, quando lhe coube passar a seu campo de atividade a arte desenvolvida que o homem criara, mostrou-se à altura do companheiro e, mais previdente do que ele, soube imprimir em matéria durável a perpetuação duma cultura forte." ${ }^{46}$

Não sabemos quem seriam aqueles senhores mas, das oleiras às "crioulas baianas", passando pela pesquisa não publicada sobre as jovens trabalhadoras urbanas, vemos um tímido mas persistente interesse que, infelizmente, Heloisa não desenvolveu. Provavelmente também nunca saberemos quem seria a "talentosa jovem" que ela pretendia iniciar na pesquisa de campo na década de cinqüenta, em sua última pesquisa que, se não rendeu nenhum trabalho escrito, deu origem a um filme internacionalmente premiado ${ }^{47}$.

É pouco provável que Heloisa fosse considerada uma feminista pelas suas contemporâneas que o eram - e há evidência em seu arquivo de pelo menos uma desavença entre elas e a diretora do $\mathrm{Museu}^{48}$. Mas a imprensa inicialmente a considerou parte do movimento feminista e a apresentou, nos anos 20, como tal, em matérias com títulos do tipo "Uma victoria do feminismo" ou "Lugar à cultura e à intelligencia da Mulher!", todas elas ilustradas com uma foto em que Heloisa parece uma atriz do cinema mudo, com grandes olheiras. Todas as matérias, no entanto, aludiam a seu famoso pai. Um pouco mais adiante, nos anos 30, ela aparece no contexto da propaganda pela paz, como membro do Comitê de propaganda e luta contra a guerra, entre nomes como os de Nise da Silveira, Eugênia Álvaro Moreira, Maria Lacerda de Moura, Itália Fausta e, desde aí, sempre no contexto de reportagens sobre "mulheres ilustres". Aos poucos o nome de seu 
pai deixa de ser mencionado e ela será um dos nomes sugeridos, para o Ministério de Educação, num projeto de governo "feminista" do jornalista Mozart Lobo, cujos ministérios seriam todos ocupados por mulheres (Berta Lutz, Alzira Vargas do Amaral Peixoto, Carmen Portinho, Carlota Pereira de Queiroz eram outras) e por Carlos Drummond de Andrade na crônica "Oitenta mulheres na Academia", onde ridiculariza a proibição da entrada de mulheres na Academia Brasileira de Letras, e apresenta os nomes de mulheres que lhe parecem merecer tal honra; será entrevistada, com Rachel de Queiroz e Lucia Benedetti, a propósito de uma pesquisa que teria demonstrado ser a mulher o "sexo forte"; entrevistada por Eneida sobre sua carreira, e freqüentemente citada por Drummond em suas crônicas - até se transformar em exemplo na coluna "Mulheres de ontem e de hoje", aos sessenta anos ${ }^{49}$. De senhorinha, passando a senhorita, ou mademoiselle, como a chamava Dina Lévi-Strauss nas duas cartas que lhe escreveu, a dona (doña, como grifava Métraux), Heloisa Alberto Torres foi uma presença constante no noticiário carioca dos anos 20 aos anos 50 e terá sido um modelo importante para muitas jovens nesse período em que as mulheres começavam a freqüentar a universidade em nosso país. No âmbito da sua disciplina, nenhum antropólogo brasileiro de sua geração se empenhou tanto em assentar os alicerces da pesquisa de campo entre nós. Seu empenho não foi em vão: quando Roberto Cardoso de Oliveira retomou as expedições de campo com jovens candidatos a antropólogos na década de 60 , no mesmo Museu Nacional, e estabeleceu uma parceria com outro jovem antropólogo que vinha dos Estados Unidos, David Maybury Lewis, iniciativas que dariam origem ao Programa de Pós Graduação em Antropologia Social, retomava também uma tradição da casa. 
Revista de Antropologia, São Paulo, USP, 1997, v. 40 nº 1.

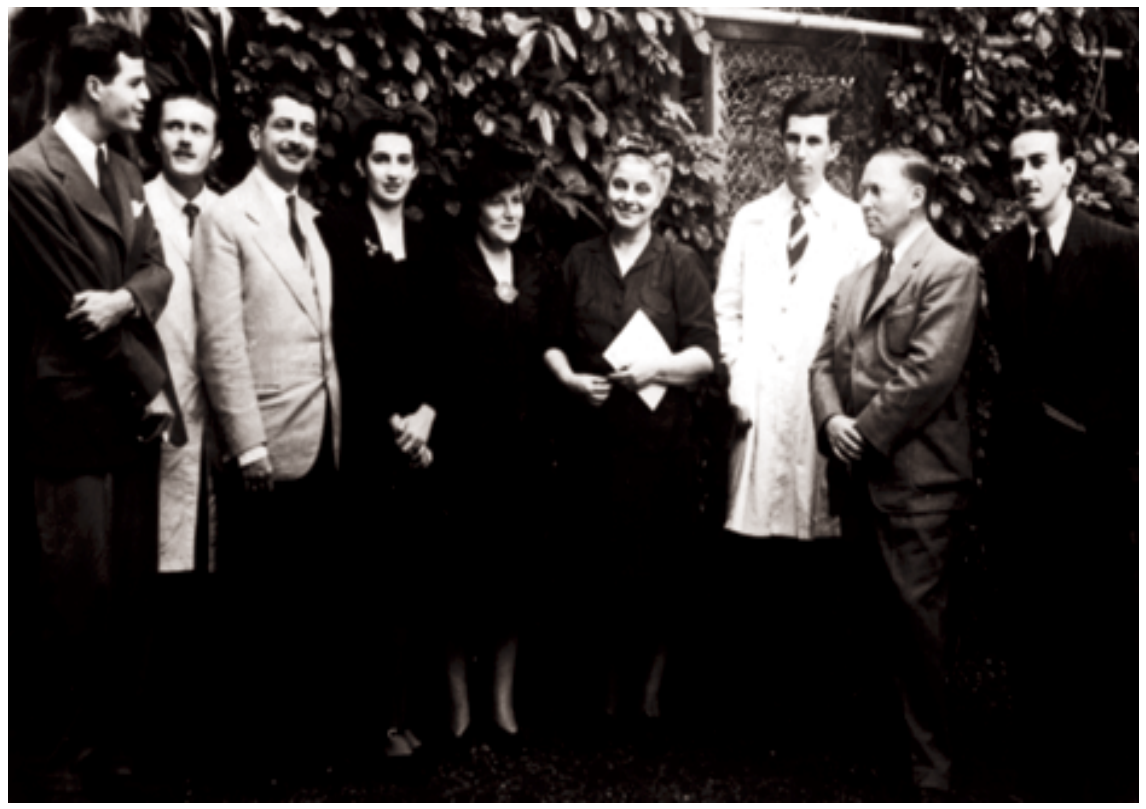

Da esquerda: Charles Wagley, Pedro Lima, Gilberto Freyre e D. Madalena, Frances Herskowits, D. Heloisa, Eduardo Galvão, Melville Herscowits, Nelson Teixeira. 


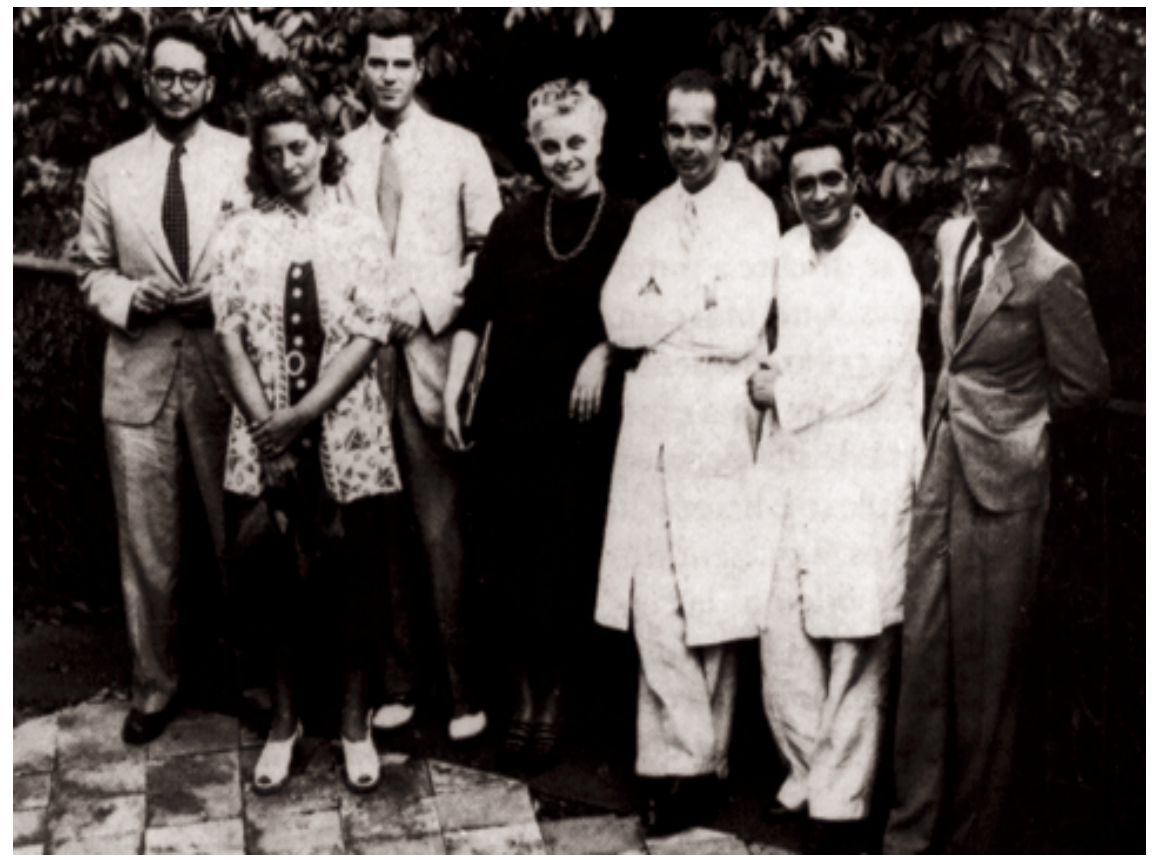

Da esquerda: Lévi-Strauss, Ruth Landes, Charles Wagley, D. Heloisa, Castro Faria, Raimundo Lopes, Edison Carneiro.

\section{Notas}

1 A genealogia da família, provavelmente feita por Marieta, encontra-se numa das gavetas dos sete arquivos de aço onde está reunida a documentação das duas irmãs. O pai de Alberto Torres, Antonio Martins Torres, chegou ao Brasil por volta de 1815 e casou-se com Carlota Ferreira de Seixas. Alberto Torres casou-se com a paulista Maria José Xavier da Silveira e o casal teve três filhos: Maria, Alberto e Heloisa. As duas irmãs nunca casaram; Alberto casou-se com Regina Moura e teve dois filhos: Rosa Maria, que se casou com o paulista Helio Moniz de Souza e Anto- 
nio Alberto, falecido solteiro, "ficando assim extinta", está anotado na genealogia, "a descendência viril de Alberto Torres." Agradeço a extrema gentileza do diretor da Casa, Itamar dos Santos, que me deixou consultar os arquivos em meio às reformas pelas quais ela estava passando, $\mathrm{e}$ o interesse carinhoso dos seus funcionários pela minha pesquisa. Agradeço também a Berta Ribeiro, Ana Maria Galano, Roberto Cardoso de Oliveira, Luiz de Castro Faria e Anna Timotheo da Costa por terem compartilhado comigo suas lembranças de dona Heloisa.

2 Bertha Lutz ingressou no Museu Nacional em 1919, ano seguinte ao da chegada de Heloisa; no seu, como no caso da primeira mulher a se inscrever para um concurso no serviço público, foi necessário o parecer de um consultor jurídico para que pudesse assumir o cargo. No mesmo ano, Bertha Lutz fundou a Liga pela Emancipação Intelectual da Mulher, depois substituída pela Federação Brasileira pelo Progresso Feminino. Sobre a trajetória de Bertha Lutz, e um bom apanhado dos argumentos contrários à qualificação das mulheres como eleitoras (Alves, 1980). Ver também as crônicas de Lima Barreto na época, para um exemplo dos argumentos contrários à participação de mulheres no serviço público. Uma das notícias sobre o concurso de Heloisa, que foi aprovada em primeiro lugar, confirma indiretamente a ambivalência reinante sobre a entrada de mulheres no serviço público. Diz a notícia: "A sua nomeação constituirá, com um ato de justiça elementar do governo, a afirmação de um dos mais interessantes espíritos femininos contemporâneos." (recorte sem data entre os papéis de Heloisa em Itaboraí).

3 Ver também a breve nota biográfica de Maria Julia Pourchet (1977) sobre Heloisa. Maria Julia, que era sua amiga, foi também sua assistente na UERJ e conselheira suplente dela no CNPI. Os dois autores listam outros cargos e encargos assumidos por ela ao longo de sua vida. A participação dela no Conselho Nacional de Proteção aos Índios está documentada e é analisada por Freire (1990); sobre sua atuação no Conselho de Fiscalização das Expedições Artísticas e Científicas, ver Grupioni (1996).

4 A única referência que encontrei sobre a primeira viagem está numa nota de um trabalho publicado em 1937 na Revista do Patrimônio Histórico e Artístico Nacional, re-editado na Revista do Arquivo Municipal do De- 
partamento de Cultura da Prefeitura do Município de São Paulo em 1938: "A frase de um vaqueiro com quem viajamos para o Pacoval do Cururú merece registro pelo pitoresco com que documenta o facto" (capões de mato chamados de ilhas, e a linguagem maritíma para descrever acidentes geográficos terrestres em Marajó): 'Branca, depois que a gente passar a ilha do Atalaia, damos numa enseada que abre na baía onde se avista o Pacoval.' Note-se que viajamos a cavalo. De facto, depois de atravessarmos um capão de mato, de chão muito limpo, e que na orla oposta à de nossa entrada tinha uma forma circular, demos num imenso campo que, na linha do horizonte, tocava o céu. Uma pequena mancha acinzentada que foi crescendo aos nossos olhos, à medida que avançamos, cortava essa linha: era o Pacoval do Cururú." (Proteção ao material arqueológico e etnográfico, seção Publicações). É uma pena que uma tão zelosa documentadora do detalhe etnográfico não nos tenha deixado mais descrições de suas experiências de campo. Em seu arquivo pessoal há uma coleção de dezesseis cartas para sua mãe, algumas já citadas no capítulo 1 , onde ela vai descrevendo as pessoas que encontra, as reuniões de que participa, as reações à Revolução de 30, registrando as encomendas que recebe de casa. Heloisa tinha 35 anos na época, mas as cartas "para minha mamãe", assinadas "da filhinha", parecem as de uma mocinha, cercada de amigos da família e com um acompanhante que a mãe exigira que fosse com ela. Deste, que parece ser um menino de recados, ela se queixa por não ajudá-la em nada ao longo de toda a correspondência e, finalmente, contra a vontade da mãe, o manda de volta para casa: "Estou tão mais feliz sozinha."

5 Sobre as dificuldades dos que vinham pesquisar no país, e não contavam com este tipo de apoio, veja-se a cômica narrativa de MayburyLewis (1991) sobre sua peregrinação pelos gabinetes oficiais na década de 50. Heloisa integrou o Conselho de Fiscalização das Expedições Artísticas e Científicas do Brasil de 1934 a meados dos anos 40 (no currículo feito por ela mesma há uma interrogação ao lado da segunda data) e o CNPI (que presidiu de 1959 a 1967, em substituição a Rondon), desde 1943 até a sua extinção em 1967, tendo permanecido na FUNAI ainda por um ano. Sua posição central fica também clara nas menções feitas à diretora do Museu por Métraux (1978) em seu diário da época. 
6 Carta de $1^{\circ}$ de agosto de 1938, Pasta Buell Quain na Casa de Cultura Heloisa Alberto Torres, de agora em diante CCHAT. No ano seguinte, Quain se matou no interior de Goiás e foi lá sepultado. Heloisa manteve correspondência com a mãe dele durante anos; em 1945 ela conta numa carta que estava fazendo o curso do Summer Institute of Linguistics para trabalhar melhor com os manuscritos deixados pelo filho.

7 Atas do CNPI, 1943, 12ª sessão, citado em Freire (1990).

8 Sigo de preferência a tradução da edição brasileira a não ser quando, como em trechos desta citação, ela omite certas palavras. O ano é 1940 e Wagley estava iniciando seu trabalho de campo com os Tapirapé.

9 Charles Wagley a Eduardo Galvão, 13 de agosto, 1947. As cartas, recortes e fotos mencionadas foram doadas por Clara Galvão ao Projeto História da Antropologia no Brasil (de agora em diante PHAB) e constituem a Coleção Eduardo Galvão.

10 Começando por uma carta formal, dele e de Nelson Teixeira em 1940 ("D.Heloisa, temos para com a senhora um sentimento de sincera gratidão, por ter nos proporcionado não só essa temporada de estudos, como a magnífica viagem que viemos realizando conhecendo assim um pouco melhor a nossa terra. Prometemos tudo fazer para corresponder a sua confiança."), Galvão passa a assinar "muitas saudades do filho", a partir de 1942 (Pasta Eduardo Galvão na CCHAT). Numa carta anterior dissera: “A senhora não parece ter sido muito feliz em escolher um 'filho' que até agora não lhe escreveu uma carta. Tenho medo que a Sra. tenha se arrependido da adoção, o que por cousa nenhuma desejo." No arquivo de Heloisa há indicações da "adoção" de pelo menos dois meninos, um seu afilhado, que morreu criança e outro, mencionado por vários de seus contemporâneos, a quem teria educado e legado uma casa, de quem há fotos quando criança, e de uma menina, a quem escreve, e de quem recebe cartas, de Paris. Isto é, há indícios de que, já aos 47 anos, Heloisa passa a assumir uma das definições do feminino aceitável e respeitável em nossa sociedade: o de mãe. 
11 Cartas de 12 de novembro de 1942; 19 de junho de 1943 e 17 de julho de 1943, CCHAT. Todas as cartas de Galvão são irônicas e algumas, como aquela em que descreve as aulas com Margaret Mead nos Estados Unidos, hilariantes. Ele sempre misturava o inglês ao português nas cartas e aportuguesava várias expressões do inglês, como "assainements".

12 James Watson a Heloisa Alberto Torres, 4 de junho,1943, PHAB/Coleção Eduardo Galvão. A existência desta carta entre os papéis de Galvão sugere que dona Heloisa considerava parte do aprendizado o conhecimento da opinião de todos, e a passou a Galvão. Ele poderia ter sido seu aluno antes, tendo se formado no Instituto Lafayette, depois Universidade do Estado da Guanabara, hoje Universidade do Estado do Rio de Janeiro, onde Heloisa dava aula desde 1939, mas os papéis timbrados do Instituto dão conta de que ele se dividia em "Departamento Masculino" e "Departamento Feminino", com endereços diferentes.

13 Heloisa Alberto Torres a Eduardo Galvão, 7 de outubro, 1943, PHAB/ Coleção Eduardo Galvão.

14 Ver a reminiscência carinhosa de Charles Wagley sobre Galvão no vídeo Charles Wagley, do Center for Latin American Studies, Gainesville, Florida.

15 Segundo Castro Faria, Pedro Lima, outro dos jovens que circulava pelo Museu na época e fez algumas excursões com Galvão, formou-se em Odontologia e veio a ocupar uma cátedra na Faculdade de Medicina mais tarde; Rubens Meanda, que como vários de seus companheiros da época, tirara o brevê na esperança de participar da Segunda Guerra, tornou-se piloto, e Nelson Teixeira suicidou-se (Castro Faria, entrevista em 17 de fevereiro de 1995).

16 Charles Wagley a Eduardo Galvão, 15 de janeiro, 1945, PHAB/Coleção Eduardo Galvão, em inglês no original. Dado o tom irônico de Wagley em outras cartas, o "grande clássico" recomendado tanto podia ser o trabalho de Oliver La Farge, citado por ele em outras ocasiões, como o seu próprio, produto da pesquisa numa comunidade maia para seu doutorado e só parcialmente publicado na época - nenhum deles, no entanto, men- 
cionado na bibliografia do livro que resultou da pesquisa dele e de Galvão. Charles Wagley só entra neste texto como testemunha dos esforços de dona Heloisa para impulsionar a pesquisa de campo; para uma análise mais exaustiva de seu trabalho e de sua trajetória, veja Rosa (1993).

17 O Conselho foi criado em 1939 para orientar a política do SPI e a relação entre ambos parece ter sido de conflito virtual ou explícito desde aí. Em 1950, o general Rondon, presidente do Conselho, reclamava a re-estruturação das duas instituições em termos que tornam este conflito muito claro, afirmando que o SPI deveria "prestar vassalagem" ao CNPI e que em alguns processos vindos do SPI "se chegou ao cúmulo de por em dúvida afirmativas desta presidência". A criação da Seção de Estudos do SPI, em 1943, "transformou o CNPI, na prática, num órgão consultivo. Caberá à SE/SPI todo o trabalho de campo relativo ao estudo dos índios, o que era atribuição do CNPI, conforme o decreto de criação do órgão.” Na gestão de Gama Malcher (1951-1955), a Seção de Estudos era responsabilidade de Darcy Ribeiro e a Seção de Orientação e Assistência de Eduardo Galvão. Ver Freire (1990), onde estão as citações; a ênfase é do autor. Em 1946, Galvão dizia que "D. Heloisa não me parece muito entusiasmada com a perspectiva de minha ida, contudo espero convencê-la em tempo. (...) Creio que como interino não poderei sair do Brasil, mas já pensei bastante sobre o caso e a solução é, assegurada a minha bolsa, dar um gesto pouco elegante ao interinato e cair no mundo. Perderei um auxílio valioso, não resta dúvida. Mas antes isso do que ficar parado e acabar um naturalista burocrata." Carta de Eduardo Galvão a Charles Wagley, 24 de agosto de 1946, PHAB, Coleção Eduardo Galvão. O "caso" de Galvão arrastou-se ainda por dois anos e ele acabou sendo processado por abandono de cargo, processo que se transformou ("graças à minha rica pessoa", diz-lhe Heloisa numa carta de 1948) em exoneração. Na CCHAT há inúmeras cartas e cartões de Eduardo e Clara Galvão para Heloisa até 1965. Galvão faleceu em 1976.

18 Este trecho está apoiado na leitura das cópias desses documentos existentes no Arquivo Heloisa Alberto Torres no Museu Nacional, cuja consulta foi grandemente facilitada pela organização prévia feita por Maria Angélica Pinto de Paula. Agradeço a Antonio Carlos de Souza Lima, que orientou o trabalho de Maria Angélica, pela gentileza de me passar cópia des- 
se material e por me facilitar o acesso ao Arquivo. O processo administrativo aberto pela reitoria leva o número 5008/46 e no Arquivo há uma listagem manuscrita de toda a documentação incluída nos três volumes que somam quase trezentas páginas.

19 Dos 21 naturalistas que assinaram vários manifestos contra Heloisa, sete eram do quadro permanente: nove eram naturalistas-auxiliares, em "estágio probatório"; um era naturalista extra-numerário mensalista, que passara de servente para esta categoria; outro tinha sido carteiro e três eram preparadores sem concurso. Nos documentos do Arquivo há várias menções ao "uso abusivo", por parte destes últimos, do título de "naturalistas" e uma carta apenas com as iniciais do autor, L.E.M. (Luiz Emídio de Mello Filho, provavelmente), dirigido a Carneiro Leão, que presidia a comissão de inquérito, caracterizando o grupo . "E quem são eles? Indivíduos profundamente inferiorizados, portadores do complexo de inferioridade em sua forma agressiva e, portanto, quasi perdidos para a sociedade a menos que submetidos a um tratamento psicanalítico ao qual não é de esperar que se submetam voluntariamente. Aqui, falo como médico que também sou." Na folha de rosto do documento, há uma anotação na letra de Heloisa: "não foi enviada". Os principais porta-vozes do grupo eram Othon Leonardos, Newton Dias dos Santos, Haroldo Pereira Travassos, Carlos de Paula Couto e Emanoel Martins.

20 Othon Leonardos, autor de graves acusações à diretora, parece ter esquecido o caso do Museu anos depois. Na apresentação de seu depoimento ao CPDOC registra-se: "Em 1946 elegeu-se diretor dessa Instituição, não chegando, entretanto, a assumir o mandato, em função de sua nomeação para o cargo de assessor da Secretaria Geral do Conselho de Segurança Nacional, que exerceu até 1956." Leonardos (1899-1977) era livre-docente em Geologia Econômica na Escola Politécnica, onde se formara, e ocupava também a cadeira de Geologia e Paleontologia da Faculdade Nacional de Filosofia. Depois de sua aposentadoria, pelo Museu, em 1954, passou a dirigir a Mannesmann Mineração S.A. em Minas Gerais até 1972 (acervo de depoimentos FINEP/CPDOC, 1984). Ele estava, portanto, no Conselho, em 1948, quando este vetou a criação do Instituto da Hiléia Amazônica, o que causou grande aflição em Heloisa, presidente da comissão interina para sua criação e estando então em Paris para uma reunião sobre o Instituto: "Pau- 
lo (Carneiro) acaba de me telefonar que a Comissão de Segurança Nacional acaba de recusar o Instituto da Hiléa. Parece que Paulo está chamado ao Brasil para prestar declarações. Nem sei o que pensar, ou fazer." Carta a uma pessoa da família não identificada, na pasta dela na CCHAT.

21 O caso das eleições foi tratado ainda no âmbito do Ministério da Educação, também resultou num processo administrativo e sua conseqüência foi a punição, com suspensão, dos dois naturalistas envolvidos na agressão no dia da votação. Na mesma carta a Wagley citada antes (n.17), Eduardo Galvão dizia: "Não temos feito outra coisa no Museu que trabalhar na exposição, e como estamos longe do fim. A situação permanece a mesma. Inquéritos, processos, representações e o diabo para cima de D. Heloisa. Não é para menos, os pequeninos estão dando tudo para tomarem conta do negócio, aproveitar-se de tudo o que foi feito até agora, para então reabrir o Museu e fazer a 'caveira' de nossa querida amiga. Nós não podemos senão ativar ao máximo o trabalho, pois si conseguirmos abrir ao público a exposição de antropologia, a batalha está ganha para o nosso lado." A exposição de antropologia foi aberta ao público em abril de 1947. Ver Faria (1949), conferência que abriu a exposição.

22 Alberto Childe tinha sido o encarregado da Coleção de Antigüidades Clássicas do Museu, e no documento fotografado existente no Arquivo de Heloisa no Museu Nacional, aprova as medidas tomadas por ela para a conservação dos sarcófagos; Price era paleontólogo, da Universidade de Harvard, especialmente contratado para desmontar o Megatério e através do documento, onde dá detalhes técnicos do que foi feito, ficamos sabendo também que treinara Carlos de Paula Couto para remontá-lo, num estágio que este fez com ele na Argentina. O megatério, personagem muito fotografado durante todo o caso, ainda pode ser visitado no Museu Nacional.

23 Métraux registrava em seu diário em 1939 que dona Heloisa "se plaint néanmoins du régime et des lois qui combattent le cumul des salaires. Tous les employés ont déserté le musée pour s'adonner à l'enseignement." Sobre a importância da criação das faculdades de filosofia para a institucionalização da ciência no Brasil, ver Schwartzman (1979). 
24 Newton Dias dos Santos dissera, em seu depoimento à comissão, que "a impugnação da mesa (eleitoral) se tornou necessária devido à provocação efetuada pelo Sr. P.L., que usando das clássicas táticas comunistas de que é perito...”. Ele, José Oiticica, Romualdo Ferreira de Almeida e Haroldo Pereira Travassos queixaram-se da censura que teriam sofrido à Associação Brasileira de Escritores, queixa que teve como conseqüência uma carta de seu presidente, Guilherme Figueiredo, à Heloisa, pedindo a versão dela do caso. Heloisa responde que "censura não houve" e encaminha os manuscritos corrigidos pelos autores, concluindo: "Não se trata aqui, de um caso de liberdade de pensamento, que cumpre distinguir nitidamente da 'indústria de publicidade procurando prevalecer sobre o pensamento', traço característico da campanha promovida por alguns naturalistas do Museu contra sua diretora."

25 Em 1935, Heloisa chegara a enviar uma carta retirando-se da Sociedade dos Amigos de Alberto Torres, em protesto a certos comunicados à imprensa sobre "a inconveniência dessa ou daquela corrente imigratória, em nome da mais duvidosa argumentação científica, e assim, postos à margem os métodos de pesquisa utilizados pelo patrono, chegou-se a falsearlhe o pensamento." Parece ter recomposto suas relações com a Sociedade mais tarde, já que seu nome volta a aparecer entre os sócios anos depois. (Pasta Sociedade dos Amigos de Alberto Torres, CCHAT).

26 A própria Heloisa é ambígua em relação à denominação de seu cargo: nos documentos que assina, quase sempre se refere a si mesma como diretor; a mesma ambigüidade se nota na documentação de seus interlocutores e foi mantida aqui nas transcrições.

27 Os documentos do Arquivo de Heloisa no Museu Nacional estão todos comentados à margem por ela, numa letra inconfundível (numa carta engraçada a Buell Quain, que parece ter criticado sua letra, ela escreve todo um parágrafo em "letra de imprensa"; desiste, e diz a ele que faça um esforço para lê-la.) Ao lado de outras frases deste documento, como "detesta a democracia", ela escreveu "falso" e ao lado desta: "citem os fatos". É interessante a menção ao "matriarcado" já que, além de Bertha Lutz e da própria Heloisa, parece que não havia nenhuma outra mulher 
trabalhando no Museu em cargos de pesquisa. Mas veja a nota 48. Em outros documentos os seus opositores falavam em "oligarquia", já que a secretaria e o arquivo estavam a cargo da irmã de Heloisa e a biblioteca com uma "sobrinha". Heloisa sublinhou com lápis vermelho o "sobrinha": tanto ela, como sua irmã Marieta, funcionária do Museu, eram solteiras. Sua única sobrinha casou-se com um paulista aos dezesseis anos e mudou-se para São Paulo.

28 O único ponto da entrevista de Newton Dias dos Santos que Heloisa deixou sem resposta parece ser justamente uma tentativa dele de arejar rumores. Comentando a decisão dela de fechar o Museu às 17 horas, contra o que também se insurgiam os naturalistas, acrescenta que Heloisa "declarou que havia razões muito sérias para não conceder o pretendido, e que não podia declarar quais eram estas razões, deixando entrever a existência de fatos graves, com ofensa para a nossa própria reputação." Durante os trabalhos da comissão nomeada pela Universidade, o mesmo naturalista circulou um manifesto em que pedia o desmentido de colegas a uma declaração que teria sido feita à comissão por José Cândido de Carvalho, de que ele ameaçara "com fatos da vida íntima", os que "não votassem contra a diretora". Assinam todos os opositores de Heloisa. Rumores à parte, é interessante o modo como a votação em Othon Leonardos é expressa no documento.

29 Trecho da carta citada: "Certamente conhece V.S. a (...), figura típica de intersexuado e por isso psiquicamente desequilibrado, instável, irritadiço, ilógico, contraditório e irresponsável." Entre os papéis de Heloisa há cópia de outra carta, "particular", enviada pelo chefe da seção de administração do Museu ao redator do Diário da Noite. Diz ele que Heloisa, "por um natural sentimento feminino, não quis adiantar cousas que mudariam inteiramente o aspecto da questão (nessa questão, eu costumo dizer que se o Diretor fosse um homem as cousas não teriam chegado ao ponto em que chegaram..."). E também tematiza a personalidade de um dos inimigos de Heloisa: "Adamado, de voz fina. Integralista. Sua crítica caracteriza-se pelo ataque pessoal."

30 A análise é devedora, como se percebe, de Douglas (1976). Analisando a simbologia de gênero dos Hagen, M. Strathern (1987), mostra que, apesar de todas as diferenças entre a nossa e a sua sociedade, lá como aqui 
estes atributos são manipuláveis: “..indivíduos podem cruzar a fronteira (homens de status baixo são 'como mulheres', mulheres de prestígio são 'como homens'). Uma mudança de status (um 'big man' que não dá certo, uma mulher que prova ser como homem) é sempre possível." É esta possibilidade de manipulação que mostra que é só por uma ficção sobre a qual se concorda socialmente que se pode pensar nas categorias masculina e feminina como formando dois conjuntos estanques. De fato, os atributos das categorias masculina e feminina formam um continuum e, de certo modo, "circulam" de um a outro polo. Parece ser, justamente, esta circulação "imprópria" que os guardiães do modelo dos conjuntos estanques denunciam: a impropriedade de uma "mulher" se comportar como "homem", ou vice-versa. Ver alguns exemplos dos perigos desta circulação para a liberdade das pessoas em Corrêa (1983). No contexto, é interessante que os opositores de Heloisa tenham escolhido a palavra matriarcado para definir sua atuação, denotando ao mesmo tempo sua pertinência (atribuída) ao campo feminino e ao campo antropológico.

31 O cartão de Afrânio Peixoto não tem data; o de Baldus é de março de 1946: pastas com os nomes de seus autores, CCHAT.

32 Sobre a Universidade do Distrito Federal, iniciativa de Anísio Teixeira, e toda a disputa em torno da educação superior no Estado Novo, ver Schwartzman, Bomeny e Costa (1984). Castro Faria (1984) comenta: "Foi grande a disputa por esses cargos e é claro que só os participantes da facção dominante do campo intelectual naquele momento tiveram acesso a eles." Como Schwartzman e suas colaboradoras mostram, mesmo alguns integrantes da "facção dominante" foram contrariados. No caso específico da cadeira de Antropologia e Etnografia, dizia Alceu Amoroso Lima em carta a Capanema, ao renunciar à posição de diretor da nova faculdade: "Hoje, conhecendo melhor o meio, sei perfeitamente que será impossível afastar o Almir de Andrade, (...) o Arthur Ramos (ainda é, a despeito de tudo, o menos perigoso), o Faria Góis, etc. (...)"

33 A ênfase nos estudos de comunidade, na Escola de Sociologia e Política, levou muitos contemporâneos a definir a Escola como "o lugar da empiria" por oposição ao "templo da teoria" que seria representado pela Faculdade de Filosofia. Vilma Chiara, que enfatiza sua formação como pesquisado- 
ra de campo na Escola, observa: "A USP era outro mundo, um mundo nobre do intelectual, um intelectual mais preocupado com os aspectos sociais, mais teórico. A gente era muito na prática, recolhia o material e publicava os dados etnográficos que tinham sido encontrados, enquanto que na USP a idéia era a teoria. Quando eu ia na USP, com muito respeito, estou entrando no templo do saber, limpava os sapatinhos da poeira da pesquisa de campo." Depoimento ao PHAB, em novembro de 1987, também registrada no vídeo Cem anos de antropologia: imagens brasileiras, Unicamp, 1994.

34 A história da SBAE está contada em detalhes por Azeredo (1986). Esta pesquisa é a fonte da documentação citada neste trecho, a menos que haja indicação em contrário. Sobre a carreira anterior de Arthur Ramos, mais ligada à Medicina Legal, ver Corrêa (1982).

35 Entre os papéis de Heloisa há uma nova portaria, de 1952, assinada pelo ministro Simões Filho, designando a ela e a Edgar Roquette-Pinto, Eduardo Galvão, Luiz de Castro Faria, Pedro Lima e Tarcisio Messias para compor a comissão organizadora da I Reunião Brasileira de Antropologia.

36 Esta história bem poderia ser ilustrada por uma foto do arquivo de Heloisa na qual ela aparece com uma tora sobre o ombro e com um sorriso maroto no rosto.

37 Castro Faria defende aqui a mesma posição que expressou em outro texto, de 1942, onde afirmava: "O Museu Nacional, entretanto, continua a ser o único instituto de pesquisa onde a antropologia é cultivada em todos os setores de seu amplo domínio...” (citado por Azeredo).

38 Wolf Lepenies (1984) retoma a expressão de Merton em sua proposta de uma "história das disciplinas" e acrescenta: "Sublinho, com ênfase, que os processos de institucionalização implicam em atos de recusa: as disciplinas adquirem as suas identidades não apenas através da afirmação, mas também pela negação. Elas não só devem declarar quem desejam seguir, mas também a quem desejam abandonar". É claro que as mesmas estratégias operam no interior das disciplinas. 
39 O caso virou assunto de jornal e ambas, Heloisa e Marina, foram atacadas nos noticiários como empenhadas em "defender as bolsas e não os interesses do ensino". O irônico nessa disputa é que Edison Carneiro, um grande campeão dos interesses dos negros, foi outro, além de Maria Alice Moura Pessoa, a tentar se inscrever no concurso aberto depois da morte de Arthur Ramos. Os três, eles e Heloisa, pediram ao Conselho Universitário a concessão de "notório saber" para suprir a ausência de títulos - pedido negado em todos os casos. Marina e Heloisa foram eleitas como integrantes do primeiro Conselho Científico da ABA na reunião da Bahia. Os que trabalharam com Marina a lembram como uma pessoa gentil, que estimulava os interesses de pesquisas dos alunos e que os protegeu no período da ditadura militar, tendo morrido depois de ser presa "para averiguações" em 1968.

40 Numa conferência intitulada As novas diretrizes da antropologia, proferida na sessão inaugural da SBAE, em agosto de 1941, Ramos, nas palavras de Azeredo, que resume a conferência: "Alertou não ser mais possível circunscrever o estudo da Antropologia Física (Biológica) e da Antropologia Cultural ao universo daquelas culturas denominadas de 'primitivas' - por não ser objeto da SBAE a prática daquela ciência de museu, criada para a burocratização do pitoresco, do bizarro. Ademais, informou Ramos o fato de se haver tornado consensual para a ciência antropológica que mesmo os povos considerados mais 'primitivos' partilham culturas de estrutura dinâmica em constante fluxo de transformação."

41 Segundo Castro Faria, o concurso acabou não se realizando, o que parece confirmado por Azeredo que diz ter Marina assumido "a interinidade da cátedra". Na CCHAT, na pasta de Heloisa, há o rascunho de uma carta para o então diretor da Faculdade Nacional de Filosofia, Eremildo Viana, pedindo a devolução de seus documentos e o cancelamento de sua inscrição no concurso "pois já se passaram sete anos sem que ele se realizasse". Consta também uma certidão do Conselho Universitário que, ao contrário do que diz Azeredo, em 1950 reconheceu a equivalência de seus méritos a uma livre-docência, registrando em ata, numa linguagem cuidadosa, que esta era porém uma questão inteiramente separada da do concurso. 
42 Heloisa cita as "quatro moças" que foram "instruídas" por Roquette-Pinto para fazerem a pesquisa: Emilie Saldanha da Gama, Laura da Fonseca e Silva Brandão e Noemia Alvares Salles, além dela. Numa entrevista de 1952, dada a Eneida, Heloisa lembra que, logo que saiu do Colégio Sion, onde estudava, um grupo de moças - duas filhas de João Baptista de Lacerda, uma sobrinha de Pacheco Leão, Marieta e ela - pediram a Roquette Pinto que organizasse um curso para elas. A menção sugere que outras moças da sociedade carioca (filhas ou sobrinhas de), como Heloisa, faziam estágios não remunerados no Museu. Numa outra entrevista, Heloisa cita também as traduções para o francês que fazia de textos de Roquette Pinto. Numa entrevista em 1988, a propósito de Emilia Snethlage, Maria Luisa Hussak van Velthen, que também trabalhou no Museu na década de vinte, lembrava das traduções que fazia, do alemão, para Roquette Pinto. A pesquisa de Roquette Pinto foi apresentada ao I Congresso Brasileiro de Eugenia, em 1929 e publicada em 1978. Sobre a trajetória de Roquette Pinto, ver Ribas (1990).

43 Heloisa cita duas outras mulheres interessadas na questão: Julia de Magalhães Viotti, que publicou em 1933 uma Contribuição à antropologia da moça mineira e Maria Julia Pourchet, a quem agradece a comunicação de dados sobre a pesquisa por ela feita com alunas de escolas públicas do Distrito Federal.

44 Fróes da Fonseca, catedrático de anatomia na Faculdade de Medicina do Rio de Janeiro (cujo assistente era José Bastos de Ávila, autor do romance sobre Heloisa), dera a aula inaugural de um curso de antropologia no Museu Nacional em 1932 e definira a antropologia como "a biologia comparativa dos grupos humanos", definição completada assim por RoquettePinto: "encarados do ponto de vista do sexo, da idade e da raça". No mesmo curso, Bastos de Ávila dera aulas práticas sobre "noções de estatística aplicada à biometria". Heloisa deve ter sido aluna aplicada: as mesmas curvas e cálculos apresentados no livro de Bastos de Ávila freqüentam esse texto fragmentado. Há inclusive uma pequena nota orgulhosa sobre a diferença entre a variação contínua e a variação descontínua: "fato este sobre o qual parece-me que fui a primeira a chamar a atenção." "A Anemone silvestri pode, na verdade, apresentar 7,8 ou 9 pétalas, nunca porém 7,0125 ou 7,02364 etc.” Ver Ávila (1935). 
45 Sabendo o desfecho da disputa em cujo contexto o trabalho foi preparado, não é de admirar que ele não tenha sido publicado. Com 45 páginas, tamanho comum às teses de concurso da época, tem uma estrutura de artigo pelos padrões atuais e contém muitas informações que interessariam a um campo para o qual Heloisa provavelmente nem pensou em contribuir, o da moda. É interessante que a tese de Gilda de Mello e Souza, "A moda no século XIX", só publicada muitos anos depois, tenha sido defendida no mesmo ano. No Arquivo de Heloisa no Museu há uma caixa com várias amostras dos panos africanos que ela analisa em seu texto.

46 Lévi-Strauss (1986), concorda com sua primeira percepção: "Sem pretender remontar às origens, o fato é que, na América, o mais freqüente é a cerâmica ser uma arte feminina. (...) Demiurgo em pequena escala, a ceramista também ciumenta restringe uma matéria em liberdade. Modelada e fixada pelo cozimento numa forma imutável, essa matéria, por sua vez, restringe, ao 'culturalizá-las' substâncias vegetais e animais ainda no estado da natureza". No contexto da luta pela direção do Museu, Heloisa teria gostado das relações que Lévi-Strauss estabelece entre a preguiça e a oleira. Com essas observações de Heloisa à nossa frente, podemos reler também o romance de Bastos de Ávila (1990): ao fazer sua personagem destruir a teoria do trançado, ele não estava, de certo modo, corroborando a idéia inicial dela, abandonada, parece, a contragosto?

47 Numa carta de Carl Withers, de outubro de 1956, ele diz: "Estou extremamente interessado em ajudá-la a treinar essa mocinha (Geraldo diz que ela é muito talentosa), e o jovem, e quem mais você tiver disponível para o trabalho de campo." Comparar com a ênfase anterior de Heloisa, na carta a Ramos, sobre o treinamento oferecido a rapazes. O filme é Arraial do Cabo, dirigido por Paulo Cesar Saraceni. Ver as lembranças do diretor a respeito da pesquisa em Saraceni (1993).

48 Numa carta às diretoras da União Universitária Feminina, Carmen Portinho, Maria Rita Soares de Andrade, Marianna Brito, Izolina Segadas Viana e Izabel do Prado, Heloisa explica porque cancelara a inscrição de mulheres para o concurso de naturalista auxiliar extra-numerário. Começa mostrando as bases do argumento que seus inimigos usaram na luta pela direção do Museu, ao dizer que quando assumiu a direção, o Museu tinha 
seis mulheres como funcionárias: "hoje tem 38 e isso se fez por minha direta iniciativa. A secção de administração e a biblioteca são chefiadas por mulheres." Depois diz que as razões que expõe na carta "revestem-se de caráter confidencial. Nunca argüiria, de público, tais razões, nem mesmo para justificar a atitude que assumi. Sofrerei, sem protesto, a injustiça." Lembrando o exemplo de Emilia Snethlage, diz que das três naturalistas auxiliares que o Museu tem, duas não se recusavam a fazer excursões ("parte integrante das funções do naturalista"), quanto à outra, recusara porque "o marido não lho permitiria" e dos 365 dias de trabalho, compareceu 265, por ter tido filhos e doenças. Explica que três mulheres tinham se inscrito no concurso, duas não compareceram à defesa de tese e a terceira, que concorria à vaga em Antropologia Física, apresentara um trabalho sobre música indígena. Agradece a elas a oportunidade de deixar registradas para a história as suas razões e conclui: "As condições, no futuro serão outras, pelo menos eu o espero." Pasta de Heloisa, na CCHAT.

49 Os recortes são de vários jornais cariocas e estão na Pasta Heloisa Alberto Torres na CCHAT.

\section{Bibliografia}

\section{ACERVO DE DEPOIMENTOS FINEP/CPDOC}

1984 História da ciência no Brasil, Rio de Janeiro, Fundação Getúlio Vargas.

ALVES, B.M.

1980 Ideologia e feminismo - a luta da mulher pelo voto no Brasil, Petrópolis, Vozes.

ÁVILA, B.

1935 Questões de anthropologia brasileira, Rio de Janeiro, Biblioteca de Divulgação Científica, Civilização Brasileira, S.A.

1990 Três heroínas do romance antropológico brasileiro, Primeira versão(22), IFCH/Unicamp. 


\section{AZEREDO, P.R.}

1986 Antropólogos e pioneiros: a história da Sociedade brasileira de antropologia e etnologia, série Antropologia (9), São Paulo, FFLCH/USP.

CORRÊA, M.

1982 As ilusões da liberdade - a Escola Nina Rodrigues e a antropologia no Brasil, São Paulo, tese de doutorado, USP.

1983 Morte em família, Rio de Janeiro, Graal.

FARIA, C.

1942 “A antropologia no Brasil e na tradição do Museu Nacional”, Revista do Brasil, dezembro.

1949 As exposições de antropologia e arqueologia do Museu Nacional, Rio de Janeiro, Departamento de Imprensa Nacional.

1978 "Heloisa Alberto Torres (1895-1977)”, Anuário Antropológico/1977, Rio de Janeiro, Tempo Brasileiro.

1984 "A antropologia no Brasil. Depoimento sem compromissos de um militante em recesso", Anuário Antropológico/82, Fortaleza/Rio de Janeiro, Univ. Federal do Ceará/Tempo Brasileiro.

DOUGLAS, M.

1976 Pureza e perigo, São Paulo, Perspectiva.

FREIRE, C.A.R.

1990 O Conselho nacional de proteção aos índios na gestão Rondon (19391955), Rio de Janeiro, dissertação de mestrado em antropologia, Museu Nacional.

GRUPIONI, L.D.B.

1996 Coleções e expedições vigiadas: os etnólogos no Conselho de fiscalização das expedições artísticas e científicas no Brasil, São Paulo, dissertação de mestrado em antropologia, USP. 
LEPENIES, W.

1984 "Interesting questions in the history of philosophy and elsewhere", in RORTY, R., SCHNEEWIND, B. e SKINNER, Q., Philosophy in history, Cambridge, Cambridge University Press.

LÉVI-STRAUSS, C.

1986 A oleira ciumenta, São Paulo, Brasiliense.

MAYBURY-LEWIS, D.

1991 O selvagem e o inocente, Unicamp, Campinas.

MÉTRAUX, A.

1978 Itinéraires, I-1935 1953, Payot, Paris.

PINTO, R.

1978 "Notas sobre os typos anthropológicos do Brasil", Ensaios de antropologia brasiliana (1933), São Paulo, Cia. Editora Nacional/Ministério da Educação e Cultura.

POURCHET, M.J.

1977 "Heloisa Alberto Torres", Revista Ciência e Cultura.

ROSA, F.T.R.

1993 A aliança e a diferença: uma leitura do itinerário intelectual de Charles Wagley, dissertação de mestrado em antropologia, Unicamp.

RIBAS, J.B.

1990 O Brasil é dos brasilianos: medicina, antropologia e educação na figura de Roquette Pinto, dissertação de mestrado em antropologia, Unicamp.

SARACENI, P.C.

1993 Por dentro do Cinema Novo, Rio de Janeiro, Nova Fronteira. 
Mariza Corrêa. D. Heloisa e a Pesquisa de CAMPo

\section{SCHWARTZMAN, S.}

1979 Formação da comunidade científica no Brasil, Rio de Janeiro/São Paulo, FINEP/Cia. Editora Nacional.

SCHWARTZMAN, S., BOMENY, H. e COSTA, V.

1984 Tempos de Capanema, São Paulo, Paz e Terra/Edusp.

STRATHERN, M.

1987 "No nature, no culture: The Hagen case", in MACCORMACK, C. e STRATHERN, M (eds.), Nature, culture and gender, Cambridge, Cambridge University Press.

WAGLEY, C.

1988 Lágrimas de boas vindas - os índios Tapirapé do Brasil Central, Belo Horizonte/São Paulo, Itatiaia/Edusp.

WAGLEY, C. e GALVÃO, E.

1961 Os índios Tenetehara: uma cultura em transição, Rio de Janeiro, Serviço de documentação/MEC.

ABSTRACT: Heloisa Alberto Torres (1895-1977) is widely recognized in corridor talk as an important persona in the tradition of the history of our discipline but hardly mentioned in our academic work. Did she really contributed to the building up of Anthropology in Brazil? In an attempt to answer this question, I hope also to persuade young investigators to do research in the few archives we have left and to pursuit many other personae we usually do not take as part of our history.

KEY WORDS: Brazilian anthropology, history of anthropology, genre, Museu Nacional.

Aceito para publicação em novembro de 1996. 